\title{
Corporate Capital Structure and Regulation of Bank Equity Holdings: Some International Evidence*
}

\author{
Jan Bartholdy \\ University of Otago, New Zealand \\ Glenn W. Boyle \\ University of Otago, New Zealand \\ Roger D. Stover \\ Iowa State University, U.S.A.
}

\begin{abstract}
Using data from six OECD countries, we examine the proposition that the costs associated with shareholder-debtholder agency conflicts can be reduced by allowing banks to hold equity in the firms to which they lend. Although the sensitivity of leverage to potential wealth expropriation is indeed significantly lower in Japan than in the U.S., no observable difference exists between the U.S. and the non-Japanese countries where banks are permitted to hold corporate equity. This "Japan effect" does not appear to be due to the Japanese keiretsu structure. We conclude that any differences in the debt-agency relationship between Japan and the U.S. are unlikely to be due to differences in restrictions on bank equity holdings
\end{abstract}

\section{Introduction}

Do agency factors influence the degree of leverage employed by business firms? And, if so, can this relationship be modified by the legal and regulatory environment in which these firms operate? In this paper, we investigate one

\footnotetext{
* For helpful comments, we are grateful to an anonymous referee, Geoff Booth, Jayant Kale, Frank Kerins, Stephen Prowse, Isabelle Weberpals, and to workshop participants at the Atlanta Federal Reserve, the 1996 Global Finance Association conference, the 1996 Southeast Asia regional conference of the Academy of International Business, the 1996 Financial Management Association conference, and Otago and Canterbury universities. For assistance with various aspects of this paper, we are indebted to Jack Huggins, Jun-Koo Kang, Tim Makinson, and Alistair Terry. None of the above is in any way responsible for any errors remaining in this paper.
}

(Multinational Finance Journal, 1997, vol. 1, no. 1, pp. 63-80)

(C) by the Multinational Finance Society, a nonprofit corporation. All rights reserved. DOI: $10.17578 / 1-1-4$ 
aspect of these issues by examining the link between international differences in capital structure and corresponding differences in the regulation of bank equity holdings.

As first noted by Jensen and Meckling (1976), a firm's shareholders may have an incentive to expropriate wealth from debtholders by making excessively risky investment decisions. As a result, debtholders require a higher return and the firm's optimal debt ratio falls. Thus, all else being equal, the greater the incentives for wealth expropriation, the lower the optimal debt ratio. Conversely, if features of the institutional structure serve to mitigate the conditions giving rise to these incentives, then the relationship between capital structure and agency factors is weakened.

Prowse (1990) examines the latter proposition by comparing the capital structure patterns of U.S. and Japanese firms during the 1980-84 period. In Japan, banks are permitted to accumulate limited shareholdings in the firms to which they lend, but this is generally prohibited in the U.S. By allowing principal debtholders such as banks to also hold corporate equity, the agency costs of debt should be reduced since shareholders have no incentive to expropriate wealth from themselves. ${ }^{1}$ Consistent with this hypothesis, Prowse finds that mean leverage in Japan is approximately $50 \%$ higher than in the U.S. and, more importantly, that the relationship between various measures of agency on the one hand, and leverage on the other, is significantly closer to zero in Japan than in the U.S. The obvious public policy implication of these findings is that liberalization of regulations on bank equity holdings may mitigate the agency problems of debt and thereby benefit domestic firms. ${ }^{2}$

However, there are at least two reasons for requiring further evidence before such a conclusion can be confidently accepted. First, Prowse confines his analysis to Japanese keiretsu firms, thereby leaving open the possibility that the U.S.-Japan differences he observes are an artifact of the keiretsu system rather than to differences in regulations on bank equity holdings per se. Second, the results of Rajan and Zingales (1995) suggest that at least some of

1. Other authors to note the importance of bank equity investment in loan clients for resolving agency problems include Berlin, John and Saunders (1994) and the U.S. General Accounting Office (1991). Moreover, dos Santos (1996) shows that prohibiting banks from purchasing firm equity may in fact reduce bank stability.

2. Other recent papers to examine the link between bank-firm ties and corporate agency issues are Hoshi, Kashyap and Scharfstein (1991) and Ramirez (1995). Using Japanese data, Hoshi et al compare the capital investment patterns of firms affiliated with a major bank lender (keiretsu firms) to those of independent firms. Using U.S. data, Ramirez compares the capital investment patterns of turn-of-the-century firms affiliated with the dominant banking house of J.P. Morgan to those of non-Morgan firms. In both cases, the latter groups of firms display significantly greater sensitivity to internal liquidity, suggesting that closer bank ties serve a monitoring role and reduce the incentive/ability for wealth expropriation. 
Prowse's findings may not be generalized to other countries that also permit banks to hold debt and equity stakes in the same firm. In a comparison of corporate capital structures in the G7 countries, they report (p.1445) no "...systematic difference between the level of leverage in the so-called bank-oriented countries (Japan, Germany, France, and Italy) and in the so-called market-oriented countries (U.S., U.K., and Canada)" and conclude that the difference between these groups of countries is reflected more in the choice between public and private financing than in the amount of leverage. However, they do not directly test any hypotheses concerning the relationship between debt and agency factors. In this paper, we attempt to shed light on this issue by extending Prowse's analysis to include four additional countries (Canada, France, Germany, U.K.) that permit banks to hold equity in the firms to which they lend. If there is general validity to the hypothesis that agency costs are reduced by the participation of banks in the equity of their corporate loan clients, then capital structure patterns in these countries should differ from those in the U.S. in a similar manner to that discovered by Prowse for Japan and the U.S.

In the next section, we provide a brief synopsis of the international differences in restrictions on bank ownership of corporate equity. Section III describes our data and empirical methodology and provides some summary statistics. Section IV presents our results. Although the sensitivity of leverage to measures of wealth expropriation is indeed significantly lower in Japan than in the U.S., no observable difference exists between the U.S. and the non-Japanese countries. This "Japan effect" does not appear to be due to the Japanese keiretsu structure. We conclude that differences in the debt-agency relationship between Japan and the U.S. are unlikely to be due to differences in restrictions on bank equity holdings. Section $\mathrm{V}$ summarizes our findings and provides some concluding remarks.

\section{Institutional Background}

We examine the capital structure patterns of firms in five countries (Japan, Canada, France, Germany, U.K.) that permit bank purchases of corporate equity and in one country (U.S.) that does not. ${ }^{3}$ Considerable diversity exists within the former group, a summary of which appears in Table 1.

According to the OECD (1992), German banks play the most prominent role of any country in the management of its nonfinancial companies. The "hausbank" system allows one bank to provide all lending and investment

3. For further information, see OECD (1992) and Pecchioli (1987). 
banking services to a client company. Not only do German banks directly control a sizeable number of large firm boards of directors, but they also exert control indirectly through large blocks of shares in nonfinancial firms and through proxy voting for other bank clients.

TABLE 1. Summary of Regulations on Bank Ownership of Non-financial Firm Equity

Canada

France

Germany

Japan

UK

USA up to $10 \%$ of firm voting shares

up to $15 \%$ of firm capital no formal restrictions up to $5 \%$ of firm capital no formal restrictions prohibited

In a similar fashion, financial institutions in Japan are known to be capable of exerting considerable control over large firms. Several authors have noted that the control imposed by Japanese banks reflects not only long term bank-client relations but also the keiretsu system in which the practice of mutually held shares among members enhances the information directly obtained by banks. This information sharing and mutual disclosure allows banks to participate in company risk and to permit a longer term focus for client management. However, in contrast to regulation in Germany, where few effective restrictions limit bank control of nonfinancial firms, the Japanese banks are subject to the Anti-Monopoly Act which limits a bank's holdings in a single nonfinancial entity to $5 \%$ of the firm's shares. ${ }^{4}$

Although there are no formal limits on U.K. banks'holdings in nonfinancial firms, prudent rules strongly affect bank policies. Any loan exposure above $10 \%$ of the bank's capital must be reported to the Bank of England. If the holdings exceed a $20 \%$ share in the nonfinancial firm equity, then there are negative consequences for the bank's capital adequacy.

4. At first glance, $5 \%$ of a firm's equity would seem insufficient to mitigate agency problems since it would not provide banks with sufficient voting power to prevent wealth expropriation. However, such a stake would generally entitle the bank to a board seat and therefore to advance knowledge of any wealth expropriation policies on the part of the firm. As a result, any additional credit required by the firm would have to be obtained from another bank, which would presumably want to know why the shareholding bank was unwilling to provide this funding. In this way, the presence of the shareholding bank provides a form of indirect guarantee against wealth expropriation. 
In France, the regulatory limit on equity holdings by commercial banks is $15 \%$ of firm capital and actual bank equity holdings in nonfinancial firms have grown dramatically since the market crash of 1987. A relatively high number of banks in France are government owned, so regulators play a role similar to that in the U.K. in that they may require a bank to increase its capital to offset the weakness in equity shares held by the bank.

A proportionate limitation on bank share holdings in nonfinancial firms also applies to Canada where the limit is $10 \%$ of the voting shares. The only exception to this rule is for investment in foreign companies, in which case a distinction is made between large and closely held banks.

The United States remains the principal country prohibiting bank equity holdings of loan client firms. These regulations originated with the Glass-Steagall Act of 1933, since which time only bank holding companies have been able to hold equity securities in their institutional portfolios. In recent years, there has been considerable pressure for reform of this act. Although such efforts are currently stalled, the post-1988 period has seen the relaxation of some of the act's provisions, particularly in the extent to which banks can undertake underwriting business.

\section{Data and Empirical Methodology}

\section{A. Data}

Our financial data were obtained from the Compustat Global Vantage tape and a detailed listing of the data items used is provided in the appendix. In any year during the 1987-92 period, the data for a firm located in any of the six countries identified in section 2 were included in our sample if and only if the firm met the following criteria:

1. The firm had a Standard Industrial Classification (SIC) code in the 2000-4000 range, i.e., manufacturing firms only.

2. The firm had annual sales of at least U.S.-\$20 million. Sales of non-U.S. firms were converted to U.S. dollars using the Global Vantage spot exchange rate prevailing on the month of the balance date.

For the firms that satisfied these criteria, Table 2 provides a breakdown by industry of mean leverage ratios in each country. The leverage ratio is defined as: 5

5. For reasons discussed in Prowse (1990), the Japanese leverage ratios are calculated as: 


$$
L E V R=\frac{\text { long-term debt }}{\text { total liabilities }+ \text { market value of equity }}
$$

For Japan, the keiretsu/non-keiretsu classification is that used in Kang and Stulz (1994). As in Prowse (1990), Japanese firm leverage is consistently higher than that for U.S. firms. In general, leverage is highest in Japan and lowest in the U.K. and Germany, essentially the same pattern as found by Rajan and Zingales (1995).

If closer bank-firm ties lower the agency costs associated with shareholder-debtholder conflicts of interest, then mean debt ratios should be higher in countries which permit banks to hold equity in their loan clients. ${ }^{6}$ In fact, the bottom row of Table 2 indicates that firm leverage in the U.S., the one country that does not permit such alliances, lies somewhere in the middle of the range of the countries examined. Moreover, a row-by-row examination reveals that there is not even a single industrial sector for which the U.S. has the lowest debt ratio while there are three sectors (Food, Tobacco, Clothing) where it actually has the highest. Of course, this pattern may simply be the result of differences in accounting conventions. ${ }^{7}$ In any event, a comparison of leverage means sheds relatively little light on the debt-agency relationship since other factors can also affect leverage and it is to these factors that we now turn.

\section{B. Empirical Methodology}

Our basic model of the relationships between debt, agency, and regulations on bank equity holdings is essentially the same as that of Prowse (1990), thereby

$$
\text { LEVRJP }=\frac{\text { total liabilities }- \text { accounts and notes receivable }}{\text { total liabilities }+ \text { market value of equity }}
$$

This adjustment resulted in superior model specification, but had no effect on the statistical or economic significance of the debt-agency relationship. For a discussion of possible biases in the leverage ratio induced by international differences in accounting treatments, see Rajan and Zingales (1995).

6. As pointed out to us by the referee, creditor banks may wish to reduce firm exposure to other forms of debt financing in order to minimize their own risk. However, as sub-optimal leverage dilutes equity values, any such tendencies are constrained by bank holding of firm equity.

7. For example, there may be accounting treatments of balance sheet items that result in the debt ratios of firms in Canada, France, Germany, and the U.K. being understated relative to U.S. firms. We know of no simple or non-arbitrary way to adjust for such biases, although in sections $4 \mathrm{~B}$ and $4 \mathrm{C}$ we make use of country dummy variables as a partial control. 
TABLE 2. Leverage Ratio Means by Manufacturing Industrial Sector

\begin{tabular}{|c|c|c|c|c|c|c|c|}
\hline \multirow{2}{*}{$\begin{array}{l}\text { Industry } \\
\text { Food }\end{array}$} & \multirow{2}{*}{$\begin{array}{r}\text { U.S. } \\
18\end{array}$} & \multirow{2}{*}{$\begin{array}{r}\text { Japan } \\
\text { keiretsu } \\
.18\end{array}$} & \multirow{2}{*}{$\begin{array}{c}\begin{array}{c}\text { Japan } \\
\text { on-keir }\end{array} \\
.16\end{array}$} & \multirow{2}{*}{$\begin{array}{l}\text { Canada } \\
\text { tsu } \\
\\
.15\end{array}$} & \multirow{2}{*}{$\begin{array}{r}\text { U.K. } \\
.08\end{array}$} & \multicolumn{2}{|c|}{ France Germany } \\
\hline & & & & & & .16 & .06 \\
\hline Tobacco & .20 & $\mathrm{n} / \mathrm{a}$ & $\mathrm{n} / \mathrm{a}$ & .09 & .03 & $\mathrm{n} / \mathrm{a}$ & $\mathrm{n} / \mathrm{a}$ \\
\hline Textiles & .26 & .30 & .17 & .29 & .07 & .12 & .13 \\
\hline Clothing & .18 & .09 & .17 & $\mathrm{n} / \mathrm{a}$ & .04 & .09 & .04 \\
\hline Lumber & .22 & .27 & .28 & .28 & .11 & $\mathrm{n} / \mathrm{a}$ & .22 \\
\hline Furniture & .16 & .16 & .12 & .08 & .04 & .30 & $\mathrm{n} / \mathrm{a}$ \\
\hline Paper & .19 & .31 & $\mathrm{n} / \mathrm{a}$ & .27 & .08 & .23 & .11 \\
\hline Printing/publishing & .15 & .12 & .12 & .18 & .09 & .08 & .02 \\
\hline Chemicals & .12 & .23 & .21 & .19 & .07 & .12 & .07 \\
\hline Petroleum/refining & .21 & .33 & .48 & .20 & .09 & .13 & $\mathrm{n} / \mathrm{a}$ \\
\hline Rubber/plastics & .20 & .29 & .27 & .32 & .06 & .19 & .08 \\
\hline Leather & .13 & $\mathrm{n} / \mathrm{a}$ & $\mathrm{n} / \mathrm{a}$ & $\mathrm{n} / \mathrm{a}$ & .04 & $\mathrm{n} / \mathrm{a}$ & .06 \\
\hline Glass/ceramics & .25 & .25 & .30 & .16 & .11 & .18 & .05 \\
\hline Steel & .20 & .31 & .29 & .20 & .07 & .23 & .16 \\
\hline Metal & .19 & .24 & .17 & .23 & .07 & .15 & .02 \\
\hline Machinery & .14 & .29 & .14 & .13 & .07 & .09 & .08 \\
\hline Electrics & .14 & .21 & .16 & .08 & .06 & .13 & .05 \\
\hline Vehicles & .20 & .31 & .28 & .13 & .10 & .09 & .07 \\
\hline Lab/research equipment & .13 & .18 & .21 & .22 & .06 & .12 & .12 \\
\hline Miscellaneous & .16 & $\mathrm{n} / \mathrm{a}$ & .13 & .18 & .02 & .10 & .10 \\
\hline Aggregate & .16 & .25 & .21 & .19 & .07 & .14 & .07 \\
\hline & $(.15)$ & $(.13)$ & $(.13)$ & $(.15)$ & $(.07)$ & $(.10)$ & $(.07)$ \\
\hline
\end{tabular}

Note: For Japan, the excess of accounts and notes receivables over payables is subtracted from the numerator - see footnote 5. $\mathrm{n} / \mathrm{a}$ indicates that insufficient data were available. The terms in parentheses in the bottom row are standard deviations

facilitating comparison with his results:

$$
\begin{gathered}
\text { LEVR }=\alpha_{0}+\alpha_{1} A G C Y+\alpha_{2} O R+\alpha_{3} N D T S+\alpha_{4} P R O F \\
+\alpha_{5} L I N T+\sum_{j=1}^{19} \beta_{j} X_{j}+e
\end{gathered}
$$

where: $\quad A G C Y=$ measure of potential agency conflict between debt holders and shareholders

$$
\begin{aligned}
O R & =\text { operating risk } \\
N D T S & =\text { non-debt tax shields } \\
P R O F & =\text { past profitability } \\
L I N T & =\text { long-term government bond yield } \\
X_{j} & =\text { industry j dummy variable }{ }^{8}
\end{aligned}
$$

8. We categorize these variables so that the intercept coefficient represents the food products industrial group. 
The only difference between our specification and that of Prowse is that we include the long-term interest rate variable LINT due to our use of pooled time series and cross-section data. However, our estimation results are unaffected by the exclusion of this variable.

Although the motivation for the model described by equation (1) is fully explained by Prowse, we shall briefly review the general idea behind it. If shareholders are able to expropriate wealth from debtholders, then the latter group will require compensation in the form of a higher expected return, thereby increasing the cost of debt and lowering the optimal debt ratio. Thus, leverage should be negatively related to opportunities for wealth expropriation. However, if the incentives to exploit these opportunities are weakened by, for example, the encouragement of closer debtholder-shareholder ties, then their effect on leverage would be correspondingly smaller. Thus, the relationship between leverage and wealth expropriation opportunities should be less pronounced for firms in countries that permit banks to hold equity stakes in their loan clients.

To test this hypothesis, we employ the following measure of wealth expropriation potential: ${ }^{9}$

$$
A G C Y=\frac{\text { cash and marketable securities }}{\text { total assets }}
$$

In general, the more liquid a firm's assets (high AGCY), the easier it is for shareholders to manipulate these in a manner that benefits themselves at the expense of debtholders. The first row of Table 3 provides sample means and standard deviations for this variable and indicates considerable variation across

9. This variable corresponds to Prowse's (1990) AD3 measure of agency potential. His other two measures are as follows:

$$
\begin{aligned}
& A D 1=\frac{\text { research and development expenditure }}{\text { sales }} \\
& A D 2=1-\frac{\text { gross fixed assets }}{\text { total assets }}
\end{aligned}
$$

We concentrate on the AD3 measure for the following reasons. First, it is the most ex-ante plausible agency measure as both alternative measures potentially pick up other effects: research and development expenditure is frequently cited as a potential source of non-debt tax shield while gross fixed assets is commonly used as an indicator of the tangible asset hypothesis of Scott (1977). Second, perhaps reflecting the above reasoning, Prowse's results were strongest for the AD3 measure of agency. Consequently, a focus on this measure provides the strongest test of the falsability of his hypothesis. Finally, using our more recent data, we were unable to replicate Prowse's US-Japan results for the other measures of agency. 
TABLE 3. Means and Standard Deviations of Regression Variables

\begin{tabular}{lcccccccc}
\hline Variable & U.S. & $\begin{array}{c}\text { Japan } \\
\text { keiretsu }\end{array}$ & $\begin{array}{c}\text { Japan } \\
\text { non-keiretsu }\end{array}$ & Canada & U.K. & France & Germany \\
& & & & & & & \\
AGCY & .103 & .192 & .220 & .045 & .098 & .104 & .093 \\
& $(.13)$ & $(.09)$ & $(.13)$ & $(.09)$ & $(.10)$ & $(.09)$ & $(.09)$ \\
OR & 53.97 & 18.36 & 6.34 & 13.78 & 23.79 & 9.51 & 5.89 \\
& $(397.0)$ & $(165.4)$ & $(13.77)$ & $(49.1)$ & $(107.9)$ & $(60.8)$ & $(10.6)$ \\
NDTS & .014 & .005 & .006 & .015 & .009 & .003 & .002 \\
& $(.03)$ & $(.01)$ & $(.01)$ & $(.03)$ & $(.05)$ & $(.01)$ & $(.01)$ \\
PROF & .100 & .060 & .066 & .095 & .116 & .065 & .026 \\
& $(.09)$ & $(.03)$ & $(.07)$ & $(.07)$ & $(.06)$ & $(.08)$ & $(.07)$ \\
Observations & 7932 & 791 & 1032 & 817 & 1927 & 627 & 641 \\
\hline
\end{tabular}

Note: Variables are defined as follows. $A G C Y$ is the ratio of cash and marketable securities to total assets. $O R$ is the standard deviation of the ratio of earnings before interest and taxes to interest expenses. NDTS is non-debt tax shields (see text for definition). PROF is the average of the ratio of net income to sales over the previous 3-year period. Standard deviations are in parentheses.

countries. The most interesting feature is the high average liquidity of Japanese firms, i.e., they have the highest expropriation potential.

The higher the probability of a firm being unable to meet its current interest commitments, the lower its potential debt capacity. Our proxy for this probability is the standard deviation (over the full sample period) of the ratio of earnings before interest and taxes (EBIT) to interest expenses:

$$
Q R=\sqrt{\text { variance }\left(\frac{E B I T}{\text { interest expense }}\right)}
$$

Table 3 indicates that operating risk is, on average, higher in the U.S. than in the other countries, although the relative difference between U.S. and Japanese keiretsu firms is lower than that found by Prowse (1990).

As first noted by DeAngelo and Masulis (1980), the tax attractiveness of debt financing is reduced by the availability of nondebt tax shields. We calculate this variable as: ${ }^{10}$

$$
\begin{aligned}
& \text { NDTS }=\text { corporate tax rate } \\
& \qquad \frac{\text { operating income }- \text { interest expense }- \text { tax paid }}{\text { sales }}
\end{aligned}
$$

10. See Prowse (1990) or Titman and Wessels (1988) for derivation. 
Table 3 indicates that, on average, NDTS is higher in Canada and the U.S. than in the other countries.

As shown by Myers and Majluf (1984), information asymmetries between management and external shareholders result in external finance being costlier than internal finance. As a result, firms have a preference for the latter and leverage should be inversely related to the availability of internal funds. To control for this relationship, we use the average of firm profitability over the previous 3 years as a proxy for internal funds, i.e., in year s, past profitability $\mathrm{PROF}(\mathrm{s})$ is given by:

$$
\operatorname{PROF}(s)=\frac{\sum_{s=t-3}^{t-1} \frac{\text { net income }(s)}{\operatorname{sales}(s)}}{3}
$$

In our sample (see Table 3), German firms are, on average, somewhat less profitable than those of other countries.

\section{Results}

\section{A. Individual Country Regressions}

We first estimate equation (1) for each of the countries individually. In these regressions, we use only Japanese keiretsu firms in order to maintain comparability with Prowse (1990); we return to non-keiretsu firms later. For each regression coefficient, we calculate both OLS and White (1980) t-statistics, but the absence of any observable difference means that only the results of our OLS regressions are reported in Table 4.

Although our primary focus is on the relationship between debt choices and potential agency conflicts, the other explanatory variables are also of interest. The operating risk variable $\mathrm{OR}$ has the expected negative sign in all cases and is statistically significant for all countries except France and Japan. ${ }^{11}$ With the exception of the U.K., NDTS has the expected negative sign, although this is significant only for France and the U.S. Finally, with the exception of Germany, PROF has the expected negative sign for all countries. ${ }^{12}$

11. Prowse (1990) also finds operating risk to be of marginal significance in explaining the capital structure of Japanese firms.

12. As pointed out to us by Geoff Booth, the insignificance of reported earnings for German firms probably reflects their known propensity to smooth earnings. 
TABLE 4. Regression Results for the Relationship Between Leverage and Agency in Individual Countries

\begin{tabular}{lcccccc}
\hline Variable & U.S. & Japan $^{\mathrm{a}}$ & Canada & U.K. & France & Germany \\
\hline Intercept & .147 & .374 & .250 & .109 & .151 & .093 \\
& $(7.4)^{* *}$ & $(12.5)^{* *}$ & $(3.1)^{* *}$ & $(5.5)^{* *}$ & $(2.1)^{*}$ & $(2.7)^{* *}$ \\
AGCY & -.329 & .121 & -.427 & -.136 & -.230 & -.298 \\
& $(20.1)^{* *}$ & $(1.9)$ & $(4.6)^{* *}$ & $(5.6)^{* *}$ & $(4.0)^{* *}$ & $(6.3)^{* *}$ \\
OR & -.017 & -.027 & -.425 & -.086 & -.062 & -.885 \\
& $(3.7)^{* *}$ & $(1.0)$ & $(2.5)^{* *}$ & $(3.9)^{* *}$ & $(.5)$ & $(2.0)^{* *}$ \\
NDTS & -.619 & -.615 & -.319 & .043 & -1.823 & -.175 \\
& $(7.4)^{* *}$ & $(1.1)$ & $(1.2)$ & $(.3)$ & $(2.3)^{*}$ & $(.5)$ \\
PROF & -.278 & -2.124 & -.587 & -.131 & -.259 & .148 \\
& $(12.0)^{* *}$ & $(8.2)^{* *}$ & $(4.2)^{* *}$ & $(2.3)^{*}$ & $(2.1)^{*}$ & $(1.2)$ \\
Adjusted $R^{2}$ & .158 & .262 & .234 & .118 & .282 & .357 \\
F-value & $46.2^{* *}$ & $10.43^{* *}$ & $7.34 * *$ & $6.97 * *$ & $6.85 * *$ & $7.82^{* *}$ \\
\hline
\end{tabular}

Note: The dependent variable is firm leverage, $L E V R$. AGCY is the ratio of cash and marketable securities to total assets. $O R$ is the standard deviation of the ratio of earnings before interest and taxes to interest expenses, scaled by a factor of 1000. NDTS is non-debt tax shields (see text for definition). PROF is the average of the ratio of net income to sales over the previous 3 -year period. Each model also includes the own-country long-term interest rate and industry dummies. Absolute values of $\mathrm{t}$-statistics are in parentheses. ${ }^{\text {a }}$ Keiretsu firms only *Significant at the $5 \%$ level. $* *$ Significant at the $1 \%$ level

Turning to the debt-agency relationship, examination of the first two columns (U.S. and Japan) reveals a similar outcome to that obtained by Prowse (1990). The $A G C Y$ coefficient is significantly negative for the U.S., but insignificantly different from zero for Japan. If this distinction is due to differences in regulation of bank equity holdings, then the additional countries in our sample should have similar coefficients to Japan. However, the remaining four columns of Table 4 offer little apparent support for this hypothesis: $A G C Y$ is significantly negatively related to leverage for firms in all non-Japanese countries, i.e., there is no obvious difference between countries which allow banks to hold the equity of loan clients (Canada, U.K., France, Germany) and those that do not (U.S.).

\section{B. Is there a Bank Regulation Effect?}

The Table 4 results for the U.S. and Japan in isolation are very similar to those obtained by Prowse (1990) for an earlier period. Thus, Prowse's findings appear to be robust with respect to estimation period. However, the reason advanced for this U.S.-Japan difference, that Japanese banks are allowed to hold corporate equity while U.S. banks are not, is not strongly supported by Table 4: other countries that allow bank holdings of corporate equity exhibit a 
debt-agency relationship more akin to the U.S. than Japan. To examine this issue further, we modify (1) so as to directly estimate the difference between the coefficient estimates for the U.S. and those for the other countries. That is, we use OLS to estimate:

$$
\begin{aligned}
\text { LEVR }=\alpha_{0} & +\alpha_{0}^{d} D+\alpha_{1} A G C Y+\alpha_{1}^{d} D A G C Y+\alpha_{2} O R \\
& +\alpha_{2}^{d} D O R+\alpha_{3} N D T S+\alpha_{3}^{d} D N D T S \\
& +\alpha_{4} P R O F+\alpha_{4}^{d} D P R O F+\alpha_{5} L I N T \\
& +\sum_{j=1}^{19} \beta_{j} X_{j}+\sum_{j=1}^{19} \beta_{j}^{d} D X_{j}+\varepsilon
\end{aligned}
$$

where $D=1$ if the firm is U.S., and 0 otherwise. Thus, in equation (2), $\alpha_{i}^{d}$, for $i=1, \ldots, 4$, estimates the additional sensitivity of U.S. firm leverage (relative to foreign firms) to fluctuations in variable $i .^{13}$ This regression is run for pooled samples of U.S. firms and, sequentially, firms from Japan, Canada, U.K., France, and Germany. The results appear in Table 5. To focus on the variables of most interest, only the $\alpha_{i}^{d}$ coefficients are reported.

In general, Table 5 strengthens the impressions gained from Table 4. Although $A G C Y$ has significantly more effect on U.S. firm leverage than on Japanese or British firm leverage, there is no observable difference between the U.S. and any of Canada, France, and Germany.

One possible reason for this finding is that the firms in our sample have little reliance on bank financing. In such a case, banks are not the principal debtholders, so closer bank-firm ties do not alleviate the stockholderdebtholder relationship. Although our data do not allow us to test this directly, an indirect test can be constructed by assuming that smaller firms are more dependent on bank financing. For each country, we therefore calculate the mean size of firms in that country during our sample period and re-estimate equations (1) and (2) using only data for firms smaller than these means. We do not report the results from this exercise as they are virtually identical to those appearing in Tables 4 and 5. We are therefore unable to conclude that the lack of any significant differences in the leverage-liquidity relationship between the U.S. on one hand, and Canada, France, Germany, and the U.K. on the other, are due to a simple lack of bank-firm agency problems.

13. Note that the inclusion of the country dummy should help to control for any biases created by differences in accounting conventions. 
TABLE 5. Regression Results for the Marginal U.S. Impact on the Relationship Between Leverage and Agency

\begin{tabular}{lccccc}
\hline Variable & Japan $^{\mathrm{a}}$ & Canada & U.K. & France & Germany \\
\hline D AGCY & -.375 & .096 & -.199 & -.100 & -.031 \\
& $(4.7)^{* *}$ & $(1.0)$ & $(4.3)^{* *}$ & $(1.1)$ & $(.3)$ \\
D OR & .013 & .434 & .069 & .046 & .828 \\
& $(.4)$ & $(2.6)^{* *}$ & $(1.7)$ & $(.3)$ & $(.7)$ \\
D NDTS & 1.033 & -.267 & -.647 & 1.195 & -.430 \\
& $(1.5)$ & $(1.0)$ & $(2.4)^{*}$ & $(.9)$ & $(.5)$ \\
D PROF & 1.631 & .343 & -.127 & -.008 & -.449 \\
& $(5.1)^{* *}$ & $(2.4)^{*}$ & $(1.2)$ & $(.1)$ & $(1.4)$ \\
Adjusted $R^{2}$ & .178 & .166 & .192 & .161 & .172 \\
F-value & $31.47^{* *}$ & $29.01^{* *}$ & $34.94 * *$ & $26.94 * *$ & $28.82 * *$ \\
\hline
\end{tabular}

Note: The dependent variable is firm leverage LEVR; see equation (2). The dummy variable $\mathrm{D}=1$ if U.S. and 0 otherwise, so each coefficient represents the additional impact on U.S. firm leverage relative to firms of the country in the corresponding column. AGCY is the ratio of cash and marketable securities to total assets. OR is the standard deviation of the ratio of earnings before interest and taxes to interest expenses, scaled by a factor of 1000. NDTS is non-debt tax shields (see text for definition). PROF is the average of the ratio of net income to sales over the previous 3-year period. Absolute values of t-statistics are in parentheses. ${ }^{a}$ Keiretsu firms only. ${ }^{*}$ Significant at the $5 \%$ level. ${ }^{* *}$ Significant at the $1 \%$ level.

The overall impression given by Tables 4 and 5 is that Japan is the odd country out, contrary to the bank equity holding hypothesis which suggests that U.S. debt choices should be unique among the group of countries we examine. To investigate this issue of Japanese uniqueness further, we examine the difference between Japanese leverage choices and those of Canada, France, Germany, and the U.K. by re-estimating (2) with D set equal to 1 if the firm is Japanese keiretsu and 0 otherwise. Table 6 contains the principal results of this exercise; again, we report only those coefficient values representing the additional impact of the corresponding variable on Japanese firm leverage relative to firms in other countries.

Inspecting the first four columns of Table 6, we see that leverage choices in Canada, U.K., France, and Germany are significantly more sensitive to wealth expropriation potential $(A G C Y)$ than are those in Japan. If potential agency conflicts can be reduced by permitting banks to hold equity in their loan clients, then we should not expect to observe such differences. With regard to the other regression variables, the most striking feature is the much-greater sensitivity of Japanese leverage choices to PROF, suggesting a greater reliance on the availability of internal funding. 
TABLE 6. Regression Results for the Marginal Japan Keiretsu Impact on the Relationship Between Leverage and Agency

\begin{tabular}{lccccc}
\hline Variable & Canada & U.K. & France & $\begin{array}{c}\text { Germany } \\
\text { Japan } \\
\text { non-Keiretsu }\end{array}$ \\
& & & & & \\
D AGCY2 & .538 & .227 & .348 & .410 & .057 \\
& $(5.0)^{* *}$ & $(3.9)^{* *}$ & $(3.9)^{* *}$ & $(4.0)^{* *}$ & $(.8)$ \\
D OR & .356 & .058 & .029 & .958 & 1.878 \\
& $(2.3)^{*}$ & $(1.7)$ & $(.2)$ & $(1.2)$ & $(4.5)^{* *}$ \\
D NDTS & .525 & -1.206 & 1.161 & -.612 & .215 \\
& $(.8)$ & $(2.5)^{*}$ & $(1.1)$ & $(.8)$ & $(.3)$ \\
D PROF & -1.550 & -1.909 & -1.946 & -2.184 & -.693 \\
& $(4.9)^{* *}$ & $(8.7)^{* *}$ & $(6.8)^{* *}$ & $(6.7)^{* *}$ & $(2.4)^{* *}$ \\
Adjusted $R^{2}$ & .264 & .510 & .381 & .524 & .353 \\
F-value & $9.51^{* *}$ & $38.78^{* *}$ & $13.76^{* *}$ & $22.38^{* *}$ & $17.41^{* *}$ \\
\hline
\end{tabular}

Note: The dependent variable is firm leverage, LEVR; see equation (2). The dummy variable $\mathrm{D}=1$ if Japan Keiretsu and 0 otherwise. We report only the $\alpha_{i}^{d}$, for $i=1, \ldots, 4$, coefficients, so each number below represents the additional impact on Japan firm leverage relative to firms of the country in the corresponding column. AGCY1 is the ratio of R\&D expenses to sales. AGCY2 is the ratio of cash and marketable securities to sales. OR is the standard deviation of the ratio of earnings before interest and taxes to interest expenses, scaled by a factor of 1000. NDTS is non-debt tax shields (see text for definition). PROF is the average of the ratio of net income to sales over the previous 3-year period. See text for definitions of other variables. Absolute values of t-statistics are in parentheses. *Significant at the 5\% level. **Significant at the $1 \%$ level.

\section{Is there a Keiretsu Effect?}

As previously stated, if allowing banks to hold the equity of their corporate loan clients reduces potential agency costs, then the leverage ratios of firms operating in the U.S., where such holdings are prohibited, should be more sensitive to agency measures than the leverage ratios of firms operating in countries where bank equity participation is allowed. In fact, however, the results of our previous sub-sections indicate that the relationship between leverage and agency is broadly similar in all countries with the exception of Japan.

What, therefore, might be driving this "Japan effect"? One obvious possibility, which can easily be tested with our current data set, is that the keiretsu system operating in Japan allows for closer bank-firm ties than is possible in the other countries, even though the latter may have more liberal regulations regarding the ability of banks to hold equity in their corporate loan clients (see Table 1). To see how this might occur, consider the comparison of Japan, which allows individual banks to hold up to 5\% of firm capital, with France, where individual banks are allowed to hold up to $15 \%$ of firm capital. On the surface, closer bank-firm ties, and therefore lower incentives for wealth 
expropriation, are possible in France. However, if the keiretsu to which an individual bank belongs holds in aggregate, say, $50 \%$, of a firm's capital, then the reverse is true.

To test this proposition, we estimate (2) for Japanese firms only, with $\mathrm{D}=$ 1 if the firm is keiretsu and 0 otherwise. The results appear in the last column of Table 6. Although the leverage ratios of non-keiretsu firms are significantly less sensitive to operating risk and past profitability, their sensitivity to our measure of agency potential is virtually identical to those of keiretsu firms. We are therefore unable to conclude that the keiretsu system causes the Japan effect in debt-agency relationships.

What, therefore, might be the source of this puzzling effect? One possibility is the pervasive influence of government agencies on Japanese financial markets. As documented by Miller (1994), agencies such as the Ministry of Finance made continual attempts to stabilize markets during the period covered by our data. As a result, there is a widespread belief that Japanese market prices were frequently independent of underlying fundamentals during this period. In such circumstances, stockholders have little incentive to expropriate wealth from debtholders, regardless of the potential for doing so. Ironically, therefore, it may be that the observed weaker debt-agency relationship in Japan is due not to more liberal regulation of bank investment decisions, but rather to a greater level of regulatory interference.

\section{Concluding Remarks}

In this paper, we have extended the work of Prowse (1990) to a multinational setting. If, as hypothesised by Prowse, agency costs are reduced by allowing banks to hold the equity of their corporate loan clients, then the leverage differences he observed between the U.S. and Japan should be mirrored in other countries that also permit such holdings. However, our evidence suggests that the capital structure choices of firms in this latter group of countries are in fact closer to those of U.S. firms than to Japanese firms, so the differences observed by Prowse do not seem to be due to differences in regulation on bank equity holdings. Moreover, this "Japan effect" does not appear to be the result of the Japanese keiretsu system. One possible reason for this phenomenon, although we are unable to test for it, is the pervasive influence of government agencies on Japanese financial markets.

Of course, our results do not constitute irrefutable evidence against Prowse's hypothesis for at least two reasons. First, given the noise in international data, our tests may just be insufficiently strong to detect the hypothesized relationship, although they appear to be strong enough to detect significant differences between Japan and the remaining countries. Second, our 
model of international debt choices, borrowed from Prowse, may be subject to specification errors which disguise an underlying relationship between regulation of bank equity holdings and potential agency conflict. An alternate approach to testing for such a relationship would consist of comparing Japanese firm leverage before and after the 1987 tightening of the regulations on permissible bank equity holdings. ${ }^{14}$ A further extension of this paper would involve examining the reasons for our finding of a significantly greater dependence of Japanese firms on internal funding. We intend to investigate both of these issues in future research.

\section{Appendix}

This appendix describes in more detail the calculation and source of the variables used in this study. The bracketed terms $(\mathrm{xx})$ refer to the corresponding variable's Global Vanatge data item number. Except where otherwise stated, all items are from the Industrials File.

Leverage

$$
\text { LEVR }=\frac{\text { long term debt }(106)}{\text { total liabilities }(118)+\text { market value of equity }}
$$

where market value of equity $=$ closing price $(3) *$ shares outstanding $(13)$ and the latter two variables are in the Issues File.

For Japan,

$$
\text { LEVRJP }=\frac{\text { total liabilities }(118)-\text { accounts and notes receivable }(63)}{\text { total liabilities }(118)+\text { market value of equity }}
$$

Agency

$$
A G C Y=\frac{\text { cash }(61)+\text { marketable securities }(62)}{\text { total assets }(89)}
$$

Risk

$$
O R=\sqrt{\operatorname{var}\left(\frac{E B I T(14)}{\text { interest expenses }(15)}\right)}
$$

14. Prior to 1987, Japanese banks were allowed to hold up to $10 \%$ of firm capital. 
Non-debt tax shields

$$
\begin{aligned}
N T D S= & \text { corporate tax rate } \\
& * \frac{\text { operating income }(14)-\text { interest expense }(15)-\text { tax paid }}{\text { sales }(1)}
\end{aligned}
$$

where tax paid $=$ total tax (23) - deferred income tax (25) and corporate tax rate to statutory corporate tax rate in firm's country as listed in the annual International Tax Summaries issued by Coopers and Lybrand; where a country has both central and local government taxes, only the former is used. If NDTS $<0$, then it is set equal to zero.

Profitability

$$
\operatorname{PROF}(s)=\frac{\sum_{s=t-3}^{t-1} \frac{\text { net income }(s)(32)}{\operatorname{sales}(s)(1)}}{3}
$$

\section{References}

Berlin, M.; John K.; and Saunders, A. 1994. Bank equity stakes in borrowing firms and financial distress. Working paper FD-94-17. New York: New York University.

Coopers and Lybrand. 1987-1992. International Tax Summaries. Wiley: New York.

DeAngelo, H., and Masulis, R. 1980. Optimal capital structure under corporate and personal taxation. Journal of Financial Economics 8(1): 3-29.

dos Santos, J. 1996. Bank capital and equity investment regulation. Working paper. Cleveland: Federal Reserve Bank of Cleveland.

General Accounting Office. 1991. Deposit Insurance: Overview of Six Foreign Systems. NSIAD-91-104.

Greene, W. 1993. Econometric Analysis (2nd ed.). New York: MacMillan.

Jensen, M., and Meckling, W. 1976. Theory of the firm managerial behaviour, agency costs and ownership structure. Journal of Financial Economics 3(4): 305-360

Kang, J., and Stulz, R. 1994. How different is Japanese corporate finance? An investigation of the information content of new security issues. NBER working paper 4908. Cambridge, Mass.: National Bureau of Economic Research.

Miller, M., 1994. Functional Regulation. Pacific-Basin Finance Journal 2(2/3): 91-106.

Myers, S., and Majluf, N. 1984. Corporate financing decisions when firms have investment information that investors do not. Journal of Financial Economics 13(2): 187-220.

OECD. 1992. Banks Under Stress. Paris: OECD.

Pecchioli, R. 1987. Prudential Supervision In Banking. Paris: OECD.

Prowse, S. 1990. Institutional investment patterns and corporate financial behavior in 
the United States and Japan. Journal of Financial Economics 27 (1): 43-66.

Rajan, R., and Zingales L. 1995. What do we know about capital structure? Some evidence from international data. Journal of Finance 50 (December): 1421-1460.

Ramirez, C. 1995. Did J.P. Morgan's men add liquidity? Corporate investment, cash flow, and financial structure at the turn of the twentieth century. Journal of Finance 50 (June):661-678.

Scott, D. 1977. Bankruptcy, secured debt, and optimal capital structure. Journal of Finance 32 (March): 1-19.

Titman, S., and Wessels, R. 1988. Determinants of capital structure. Journal of Finance 43 (March): 1-20.

White, H. 1980. A heteroskedasticity-consistent covariance matrix estimator and a direct test for heteroskedasticity. Econometrica 48 (May): 817-838. 